SKRÖPPA, T. (1984): A critical evaluation of methods available to estimate the genotype $\mathrm{x}$ environment interaction. Studia Forestalia Suecica 166: 3-14.

SNEDden, C. L. and VerRYN, S. D. (1999): An investigation into the occurrence and nature of genotype by environment interaction in Pinus patula. S. Afr. For. J.(186): 67-75.

Vega, P., Vega, G., GonzÁlez, M. and Rodríguez, A. (1993): Mejora del Pinus pinaster Ait. en Galicia. Procedings of the I Congreso Forestal Español, Lourizán, Pontevedra, p. $129-134$.
WRICKE, G. (1962): Uber eine methode zur erfassung der ökologischen streubreite in feldversuchen. Zeitung für Pflanzenzüchtung 47: 92-96.

WRight, J. W. (1976): Introduction to forest genetics. Academic Press, New York, $463 \mathrm{p}$.

XunTA-DE-Galicia (2001): O monte galego en cifras. Xunta de Galicia, Dirección Xeral de Montes e Medio Ambiente Natural, Santiago de Compostela, $227 \mathrm{p}$.

Zas, R., Merlo, E. and Fernández-López, J. (2004): Genetic parameter estimates for maritime pine in the Atlantic coast of North-west Spain. For. Genet. 11(1): 45-53.

\title{
Seed Source Variation in Growth Performance of Eucalyptus camaldulensis Dehnh. of Australian Origin in India
}

\author{
By H. S. Ginwal*, Pradip Kumar, V. K. Sharma and A. K. Mandal \\ Division of Genetics and Tree Propagation, Forest Research Institute, P.O. I.P.E. \\ Kaulagarh Road, Dehradun 248195 (Uttaranchal) India
}

(Received 25 ${ }^{\text {th }}$ May 2004)

\begin{abstract}
Results of a provenance trial of Eucalyptus camaldulensis Dehnh. laid out in 2001 at Seothi $\left(30^{\circ}\right.$ N Lat., $76^{\circ}$ E Long. and $250 \mathrm{~m}$ altitude) Haryana, a semi-arid region of India are reported and discussed. Six seed sources from Australia viz. Laura River, Emu Creek, Degrey River, Wiluna, Kennedy River, Morehead River were evaluated from nursery stage (3 months) to field performance (2 year). Two sources viz. E.tereticornis (Helenvele, Qld) and FRI-4 a local seed source were used as control (check material). Significant differences between the seed sources at nursery stage were observed for collar diameter $(\mathrm{P}<0.05)$ and number of leaves $(\mathrm{P}<0.01)$. At age 2 years, significant differences between the seed sources $(P<0.05)$ were observed for height and field survival. The two seed sources viz. Emu Creek Petford, QLD and Laura river, QLD ranked first and second for height and survival at this age. Results indicate that genetic differences exist between the sources of $E$. camaldulensis. None of the traits assessed (viz. height, collar diameter, number of leaves, number of branches and survival) was found to correlate with any of the geographical coordinates of the site (latitude, longitude and altitude). There were fair differences between phenotypic and genotypic coefficient of variability. Heritability values were fairly high for height and clear bole length in comparison to collar diameter, number of branches and survival. The relative performance of these provenances was fairly consistent throughout the period of observation. The two sources viz. Laura river, QLD and Emu Creek Petford, QLD are recommended for potential source for plantation programme under semi-arid conditions.
\end{abstract}

Key words: Eucalyptus camaldulensis, variation, provenance, seed source, genetic improvement, productivity, heritability.

\section{Introduction}

Eucalyptus camaldulensis Dehnh. is perhaps the world's most widely distributed and used tree species for planting in

\footnotetext{
*Author for correspondence: (e-mail: ginwalhs@icfre.org; ginwalhs@rediffmail.com)
}

arid and semi-arid lands (ELDRIDGE et al., 1994). It is also one of the most variable species which ranges from latitude $12^{\circ} 48^{\prime}$ $\mathrm{S}$ on the Mary river in the northern territory to $38^{\circ} 15^{\prime} \mathrm{S}$ in south western Victoria, Australia (ELDRIDGE et al., 1994). The species has been recognized in northern and southern form based on the distribution and distinct morphological characters (ELDRIDGE et al., 1994). It grows in tropical and temperate climates with rainfall from $200 \mathrm{~mm}$ to $1100 \mathrm{~mm}$ annually. The success of this species as an exotic is attributed to its superiority to other species in production of wood on infertile and dry sites, its tolerance to drought and high temperature combined with rapid growth when water is available, deep penetration of roots, tolerance of periodic water logging and soil salinity, some degree of tolerance to frost, good coppicing ability and usefulness of wood (ELDRIDGE et al., 1994). The species has been introduced throughout the Mediterranean basin and various parts of Africa and southern Asia to produce wood for fuel, posts, poles, construction timbers, pulp and paper based industries and hardwood flooring.

Selection of the right seed source of the species for a given site or region is necessary for achieving maximum productivity both in plantation forestry as well as in agroforestry systems. Due to the popularity of $E$. camaldulensis for it's various uses, and special attributes mentioned above, it has been introduced in India on large scale particularly in southern parts. The information with regard to the performance of this species in different agroclimatic zones of India is very limited. KUMARVELU et al. (1995) reported better performance of $E$. camaldulensis provenances over $E$. tereticornis in southern part of India. They found four promising provenances of $E$. camaldulensis with respect to growth and survival viz. Katherine, Richmond, Gibu river and Gilbert river. Based on published information it may be said that provenances from Murray and Darling river system and adjoining areas of Victoria, South Australia and New South Wales have been found performing superior particularly in California (EMERY and LEDIG, 1987), as well as on sites with summer drought including in Israel 
Table 1. - Details of seed source and their geographical locations.

\begin{tabular}{|c|c|c|c|c|c|c|}
\hline \multirow{2}{*}{$\begin{array}{l}\text { Seedlot } \\
\text { No }\end{array}$} & \multirow[t]{2}{*}{ Species/var. } & \multirow{2}{*}{$\begin{array}{l}\text { No of } \\
\text { parent } \\
\text { trees }\end{array}$} & \multicolumn{4}{|c|}{ Origin } \\
\hline & & & Locality & $\begin{array}{l}\text { Latitude } \\
\left({ }^{0} \mathrm{~N}\right)\end{array}$ & $\begin{array}{l}\text { Longitude } \\
\left({ }^{\circ} \mathrm{E}\right)\end{array}$ & $\begin{array}{l}\text { Altitude } \\
\text { (m asl) }\end{array}$ \\
\hline $\begin{array}{l}18276 \\
\text { (S1) }\end{array}$ & $\begin{array}{l}\text { Eucalyptus camaldulensis ssp. } \\
\text { simulata }\end{array}$ & 25 & $\begin{array}{l}\text { Laura River, } \\
\text { Qld. }\end{array}$ & 15.39 & 144.31 & 100 \\
\hline $\begin{array}{l}18548 \\
(\mathbf{S} 2)\end{array}$ & $\begin{array}{l}\text { Eucalyptus camaldulensis var. } \\
\text { obtusa }\end{array}$ & 112 & $\begin{array}{l}\text { Emu Creek } \\
\text { Petford, Qld. }\end{array}$ & 17.31 & 144.56 & 450 \\
\hline $\begin{array}{l}18658 \\
(\mathbf{S 3})\end{array}$ & $\begin{array}{l}\text { Eucalyptus camaldulensis var. } \\
\text { obtusa }\end{array}$ & 20 & $\begin{array}{l}\text { Degrey River } \\
\text { Wa. }\end{array}$ & 20.12 & 119.12 & 70 \\
\hline $\begin{array}{l}18943 \\
(\mathbf{S} 4)\end{array}$ & $\begin{array}{l}\text { Eucalyptus camaldulensis var. } \\
\text { obtusa }\end{array}$ & 6 & Wiluna, Wa. & 26.35 & 120.05 & 550 \\
\hline $\begin{array}{l}20231 \\
\text { (S5) }\end{array}$ & $\begin{array}{l}\text { Eucalyptus camaldulensis var. } \\
\text { obtusa }\end{array}$ & 63 & $\begin{array}{l}\text { Kennedy River, } \\
\text { Qld. }\end{array}$ & 15.19 & 144.11 & 100 \\
\hline $\begin{array}{l}19105 \\
\text { (S6) }\end{array}$ & $\begin{array}{l}\text { Eucalyptus camaldulensis var. } \\
\text { obtusa }\end{array}$ & 33 & $\begin{array}{l}\text { Morehead River, } \\
\text { Qld. }\end{array}$ & 15.40 & 143.19 & 100 \\
\hline $\begin{array}{l}19960 \\
\text { (S7) }\end{array}$ & Eucalyptus tereticornis & 17 & Helenvale Qld. & 15.15 & 145.14 & 200 \\
\hline $\begin{array}{l}\text { Local } \\
\text { (S8) }\end{array}$ & FRI -4 & - & FRI, Campus & 30.00 & 78.00 & 610 \\
\hline
\end{tabular}

(Karschon, 1974; Moreshet, 1981), Morocco (Destremau et al., 1973), and Pakistan (SIDDIQUi et al., 1979).

In the present study eight seed sources of Eucalyptus of Australian origin, which comprised six sources of $E$. camaldulensis and one of E. tereticornis and a local source, were evaluated under a semi-arid environment in north-western part of India. The latter one source was included in this trial to serve as control. The objective was to study the pattern and magnitude of genetic variation in growth and adaptability traits to identify the best provenance to be utilized for reforestation programme to achieve the maximum productivity and use them in future genetic improvement program of this species.

\section{Material and Methods}

Six seedlots of $E$. camaldulensis and one of $E$. tereticornis were obtained from Australian Seed Centre, CSIRO, Australia (Table 1). Open pollinated seed of local source i.e. Eucalyptus hybrid FRI-4 (inter specific hybrid of E. tereticornis x $E$. camaldulensis) was used as control. Seeds were sown directly in earthen pots containing potting mixture of sand, soil and farm yard manure in the ratio of $1: 1: 1$. Prior to sowing, the pots containing potting mixture were given fungicide treatment $(0.2 \%$ Bavistin) and kept covered with plastic sheet for 24 hours. Approximately $2 \mathrm{~g}$ of seed from each of the source was sown separately in each pot. Pots were maintained in a glass house and irrigated with fine-mist sprayer to keep the potting mixture wet throughout. Observations on germination were recorded daily till germination was completed. Two leaved young seedlings were pricked out in 200 cc root trainers containing potting mixture of sand, soil and compost (20:20:60). Transplanted seedlings in root trainers were arranged in a randomized block design and maintained in the nursery till they attained the plantable height.

Three-month-old seedlings were planted in the field (pit size $45 \times 45 \times 45 \mathrm{~cm}$ ) in August 2001 in a randomized complete block design with three replications at Seothi, which falls under the jurisdiction of State Forest Department of Haryana, India $\left(30^{\circ}\right.$ $\mathrm{N}$ Lat., $76^{\circ} \mathrm{E}$ Long. and $250 \mathrm{~m}$ altitude, approx.). The area enjoys a semi-arid type of climate with mean annual rainfall of $1100 \mathrm{~mm}$. Each source constituted a 25 tree square plot and the spacing from plant to plant was kept $3 \times 3 \mathrm{~m}$. All the 25 trees in each plot constituted the measuring unit. Observations were recorded on the trial periodically for plant height (m), collar diameter $(\mathrm{cm})$, number of branches and survival percentage. The first assessment was carried out 6 months after field planting and subsequently after 12 months and 24 months. Clean bole length (length from ground level to first branch of tree) was recorded at age 24 months.

Data were subjected to analysis of variance and Least Significance Difference test using SPSS (version 6.1) computer program (SPSS Inc. $233 \mathrm{~S}$. Wacker Drive, $11^{\text {th }}$ floor, Chicago, IL 60606-6307). Linear correlation coefficients were calculated among the studied traits, and with latitude, longitude and altitude of seed origin of the sources as described by SNEDECOR and COCHRAN (1967). Genotypic and phenotypic coefficients of variation, heritability, genetic advance and genetic gain were calculated using the method of KEMPTHORNE (1957).

Table 2. - Performance of seed sources at nursery stage (3 months).

\begin{tabular}{|l|c|l|l|}
\hline Seedlot & Height $(\mathbf{c m})$ & $\begin{array}{l}\text { Collar dia. } \\
(\mathbf{c m})\end{array}$ & No. of leaves \\
\hline S1 & 29.79 & $1.98 \mathrm{ab}$ & $11.28 \mathrm{ab}$ \\
\hline S2 & 29.29 & $1.96 \mathrm{ab}$ & $12.11 \mathrm{a}$ \\
\hline S3 & 27.57 & $2.08 \mathrm{a}$ & $10.29 \mathrm{~cd}$ \\
\hline S4 & 28.03 & $2.11 \mathrm{a}$ & $9.53 \mathrm{~d}$ \\
\hline S5 & 28.09 & $1.93 \mathrm{ab}$ & $10.72 \mathrm{bc}$ \\
\hline S6 & 26.51 & $2.10 \mathrm{a}$ & $10.40 \mathrm{bcd}$ \\
\hline S7 & 27.73 & $1.84 \mathrm{~b}$ & $11.73 \mathrm{a}$ \\
\hline S8 & 31.57 & $1.83 \mathrm{~b}$ & $11.30 \mathrm{ab}$ \\
\hline $\begin{array}{l}\text { Significance } \\
\text { level } \\
\text { CD (5\%) }\end{array}$ & $\mathbf{N S}$ & $*$ & $* *$ \\
SE \pm & & $\mathbf{0 . 1 8 9}$ & $\mathbf{0 . 9 6 1}$ \\
\hline
\end{tabular}

Means followed by the same letter $(\mathrm{s})$ do not differ $(\mathrm{P}<0.05)$ by LSD test. $* \mathrm{P}<0.05$ level of significance, *** $\mathrm{P}<0.001$ level of significance, NS - Non significant. $\mathrm{CD}=$ critical difference, $\mathrm{SE}=$ standard error of mean. 
Table 3. - Growth performance of various seed sources after field planting.

\begin{tabular}{|c|c|c|c|c|c|c|c|c|c|c|c|c|c|}
\hline \multirow[t]{2}{*}{ Seed lot } & \multicolumn{4}{|c|}{6 month } & \multicolumn{4}{|c|}{12 month } & \multicolumn{5}{|c|}{24 month } \\
\hline & $\begin{array}{l}\text { Height } \\
\text { (m) }\end{array}$ & $\begin{array}{l}\text { Collar } \\
\text { dia. }(\mathrm{cm})\end{array}$ & $\begin{array}{l}\text { No. of } \\
\text { branches }\end{array}$ & $\begin{array}{l}\text { Field } \\
\text { survival } \\
(\%)\end{array}$ & $\begin{array}{l}\text { Height } \\
\text { (m) }\end{array}$ & $\begin{array}{l}\text { Collar } \\
\text { dia. } \\
(\mathrm{cm})\end{array}$ & $\begin{array}{l}\text { No. of } \\
\text { branches }\end{array}$ & $\begin{array}{l}\text { Field } \\
\text { survival } \\
\text { (\%) }\end{array}$ & $\begin{array}{l}\text { Height } \\
\text { (m) }\end{array}$ & $\begin{array}{l}\text { Bole } \\
\text { length } \\
\text { (m) }\end{array}$ & $\begin{array}{l}\text { Collar } \\
\text { dia. }(\mathrm{cm})\end{array}$ & $\begin{array}{l}\text { No. of } \\
\text { branches }\end{array}$ & $\begin{array}{l}\text { Field } \\
\text { survival } \\
(\%)\end{array}$ \\
\hline $\mathbf{S}_{1}$ & $1.50 \mathrm{a}$ & $2.03 \mathrm{a}$ & $15.00 \mathrm{a}$ & 89.33 & $4.44 \mathrm{a}$ & $5.73 \mathrm{a}$ & $27.67 a$ & 89.33 & $7.17 \mathrm{ab}$ & $2.17 \mathrm{a}$ & 7.37 & 21.00 & $84.00 \mathrm{a}$ \\
\hline S2 & $1.47 \mathrm{a}$ & $1.80 \mathrm{ab}$ & $14.00 \mathrm{a}$ & 94.67 & $4.15 \mathrm{ab}$ & $5.13 \mathrm{ab}$ & $25.33 \mathrm{a}$ & 90.67 & $7.54 \mathrm{a}$ & $2.16 \mathrm{a}$ & 7.43 & 22.67 & $85.33 \mathrm{a}$ \\
\hline S3 & $1.22 \mathrm{~b}$ & $1.80 \mathrm{ab}$ & $13.33 \mathrm{a}$ & 85.33 & $3.29 \mathrm{~d}$ & $4.00 \mathrm{c}$ & $22.00 \mathrm{ab}$ & 81.33 & $5.81 \mathrm{~cd}$ & $2.06 \mathrm{a}$ & 5.83 & 20.00 & $72.00 \mathrm{ab}$ \\
\hline S4 & $1.11 \mathrm{~b}$ & $1.60 \mathrm{bc}$ & $12.67 \mathrm{ab}$ & 68.00 & $3.37 \mathrm{~d}$ & $4.50 \mathrm{bc}$ & $24.33 \mathrm{a}$ & 64.00 & $6.21 \mathrm{bcd}$ & $1.69 \mathrm{a}$ & 6.60 & 22.00 & $57.33 \mathrm{~b}$ \\
\hline S5 & $1.42 \mathrm{a}$ & $1.87 \mathrm{ab}$ & $13.33 \mathrm{a}$ & 88.00 & $3.85 \mathrm{bc}$ & $5,10 \mathrm{ab}$ & $25.00 \mathrm{a}$ & 85.33 & $6.53 \mathrm{abc}$ & $1.65 \mathrm{ab}$ & 6.56 & 23.33 & $84.00 \mathrm{a}$ \\
\hline S6 & $0.86 \mathrm{c}$ & $1.47 \mathrm{~cd}$ & $9.33 \mathrm{bc}$ & 77.33 & $3.41 \mathrm{~cd}$ & $4.90 \mathrm{~b}$ & $23.33 \mathrm{a}$ & 66.67 & $6.21 \mathrm{bcd}$ & $1.08 \mathrm{bc}$ & 7.16 & 27.00 & $61.33 \mathrm{~b}$ \\
\hline S7 & $0.67 \mathrm{~d}$ & $1.26 \mathrm{~cd}$ & $6.66 \mathrm{c}$ & 94.67 & $2.52 \mathrm{e}$ & $4.03 \mathrm{c}$ & $11.67 \mathrm{bc}$ & 92.00 & $5.29 \mathrm{~d}$ & $0.95 \mathrm{c}$ & 6.40 & 21.67 & $82.67 \mathrm{a}$ \\
\hline S8 & $1.05 \mathrm{~b}$ & $1.67 \mathrm{bc}$ & $8.33 \mathrm{c}$ & 88.00 & $3.56 \mathrm{~cd}$ & $4.90 \mathrm{~b}$ & $18.00 \mathrm{~b}$ & 86.67 & $6.29 \mathrm{bcd}$ & $0.84 \mathrm{c}$ & 6.70 & 25.67 & $73.33 \mathrm{ab}$ \\
\hline $\begin{array}{l}\text { Significance } \\
\text { level }\end{array}$ & $* * *$ & $* * *$ & $* * *$ & NS & $* * *$ & $* * *$ & $* * *$ & * & $*$ & $* * *$ & NS & NS & * \\
\hline CD $(5 \%)$ & 0.178 & 0.297 & 3.478 & & 0.443 & 0.804 & 5.717 & 19.34 & 1.08 & 0.593 & & & 19.21 \\
\hline $\mathrm{SE} \pm$ & 0.083 & 0.138 & 1.617 & & 0.206 & 0.375 & 2.665 & 9.01 & 0.503 & 0.276 & & & 8.96 \\
\hline
\end{tabular}

Means followed by the same letter $(\mathrm{s})$ do not differ $(\mathrm{P}<0.05)$ by LSD test.

$* \mathrm{P}<0.05$ level of significance, $* * * \mathrm{P}<0.001$ level of significance, $\mathrm{NS}-$ non significant. $\mathrm{CD}=$ critical difference, $\mathrm{SE}=\mathrm{standard}$ error of mean.

\section{Results}

Variation in growth traits at nursery stage viz. height, root collar diameter and number of leaves at the age of 3 months, varied significantly $(\mathrm{P}<0.05)$ except height (Table 2$)$. The mean values of height, collar diameter, number of branches and survival per cent after 6 months of field planting along with the statistical significance are presented in Table 3. There was appreciable range in mean values for height, $0.67-1.50 \mathrm{~m}$. (S7 and S1); collar diameter, 1.26-2.03 cm (S7 and S1); number of branches, 6.66-15.00 (S7 and S1) and field survival, 68-94.67\% (S4 and S2, S7). Seed source S1 attained a maximum height of 1.5 meter, which was statistically at par with S2 $(1.47 \mathrm{~m})$ and $\mathrm{S} 5(1.42 \mathrm{~m})$, whereas S7 and $\mathrm{S} 6$ attained 0.67 and $0.86 \mathrm{~m}$ height respectively. The sources, which showed the rapid height growth, i.e. S1, S2 and S5, also displayed better growth in root collar diameter and number of branches at nursery stage.

At the age of 12 months after field planting, significant differences $(P<0.001)$ were noticed among seed sources for height $(\mathrm{P}<0.001)$, collar diameter, number of branches and survival percentage $(\mathrm{P}<0.05)$. The growth followed a more or less similar trend as was observed at 6 month. A clear-cut distinction in the performance of the seed sources was observed at this age in which the $\mathrm{S} 1$ and $\mathrm{S} 2$ sources out ranked the rest with regard to height $(4.44,4.15 \mathrm{~m})$ root collar diameter (5.73,
$5.13 \mathrm{~cm})$, number of branches $(27.67,25.33)$ and field survival $(89.33,90.67 \%)$. Both the sources were also statistically at par in their performance in respect of the traits studied. However, the fastest growth was recorded in S1 thus making it most promising in comparison to other sources. The controls (S8 and S7) did not perform well during the period covered under observation.

The performance of the seed sources in respect of height, clear bole length and field survival varied significantly at age 24 months after field planting with S1 and S2 sources maintaining their superiority and outranking the rest. The S2 appeared to be the most promising seed source, which displayed the maximum height $(7.54 \mathrm{~m})$, clear bole length $(2.16 \mathrm{~m})$, collar diameter $(7.43 \mathrm{~cm})$, number of branches (21.67) and field survival $(85.33 \%)$. The performance of this seed source remained consistent throughout the observation period.

The correlation coefficient ( $r$ ) among the various traits across the age is presented in Table 4. Root collar diameter at nursery stage was found to have significant negative relationship $(\mathrm{P}<0.05)$ with number of leaves and field survival at age 6 and 12 months. However, number of leaves at nursery stage showed a significant positive relationship with field survival at age 6,12 and 24 months. Tree height was observed to have significant positive correlation with collar diameter $(\mathrm{P}<0.01)$ at 12 and 24 months. Similarly 6 months height showed a signifi-

Table 4. - Correlation coefficient (r) among the various traits.

\begin{tabular}{|c|c|c|c|c|c|c|c|c|c|c|c|c|c|c|c|c|}
\hline & \multicolumn{3}{|c|}{ Nursery } & \multicolumn{4}{|c|}{6 months } & \multicolumn{4}{|c|}{12 months } & \multicolumn{4}{|c|}{24 months } \\
\hline & & Height & $\begin{array}{c}\text { Collar } \\
\text { dia. }\end{array}$ & $\begin{array}{l}\text { Number } \\
\text { of leaves }\end{array}$ & Height & $\begin{array}{c}\text { Collar } \\
\text { dia. }\end{array}$ & Branches & Survival & Height & $\begin{array}{l}\text { Collar } \\
\text { dia. }\end{array}$ & Branches & Survival & Height & $\begin{array}{c}\text { Bole } \\
\text { length }\end{array}$ & $\begin{array}{c}\text { Collar } \\
\text { dia. }\end{array}$ & Branches \\
\hline \multirow[t]{3}{*}{ Nursery } & Height & 1.000 & & & & & & & & & & & & & & \\
\hline & $\begin{array}{c}\text { Collar } \\
\text { diameter }\end{array}$ & -.623 & 1.000 & & & & & & & & & & & & & \\
\hline & $\begin{array}{c}\text { Number of } \\
\text { leaves }\end{array}$ & .463 & $-.741^{*}$ & 1.000 & & & & & & & & & & & & \\
\hline \multirow[t]{4}{*}{6 months } & Height & .357 & .103 & .105 & 1.000 & & & & & & & & & & & \\
\hline & Collar dia & .409 & .114 & .021 & $.955^{* *}$ & 1.000 & & & & & & & & & & \\
\hline & Branches & .052 & .437 & -.163 & $.920 * *$ & $872^{*}$ & 1.000 & & & & & & & & & \\
\hline & Survival & .366 & $-.733^{*}$ & $.918 * *$ & .177 & .139 & -.076 & 1.000 & & & & & & & & \\
\hline \multirow[t]{4}{*}{12 months } & Height & .455 & -.298 & .591 & $.710^{*}$ & .652 & .548 & .522 & 1.000 & & & & & & & \\
\hline & Collar dia. & .451 & -.099 & .273 & .651 & .654 & .482 & .138 & $.831 * *$ & 1.000 & & & & & & \\
\hline & Branches & .009 & .558 & -.281 & $.816^{*}$ & $.790^{*}$ & $.886 * *$ & -.301 & .505 & .683 & 1.000 & & & & & \\
\hline & Survival & .512 & $-.789^{*}$ & $.869 * *$ & .268 & .248 & .005 & $.966 * *$ & .578 & .177 & -.269 & 1.000 & & & & \\
\hline \multirow[t]{5}{*}{24 months } & Height & .428 & .042 & .330 & $826^{*}$ & $.727^{*}$ & .699 & .184 & $.815^{*}$ & $.847^{\star \star}$ & $.776^{*}$ & .205 & 1.000 & & & \\
\hline & Bole length & -.015 & .418 & -.032 & $.833^{*}$ & .763 * & $.949^{* *}$ & .064 & .527 & .312 & $.740^{\star}$ & .124 & .615 & 1.000 & & \\
\hline & Collar dia. & 273 & -.038 & .419 & .334 & .245 & .228 & .124 & $.716^{*}$ & $.826^{*}$ & .478 & .076 & $.783^{*}$ & .164 & 1.000 & \\
\hline & Branches & .060 & -.082 & -.003 & -.337 & -.313 & -.488 & -.201 & -.193 & .259 & -.063 & -.327 & .042 & -.663 & .376 & 1.000 \\
\hline & Survival & .360 & -.672 & $.818^{*}$ & .429 & .366 & .195 & $.926^{\text {** }}$ & $.715^{*}$ & .328 & -.050 & $945^{\star \star}$ & .352 & .279 & .196 & -.338 \\
\hline
\end{tabular}

\footnotetext{
** Significant at the 0.01 level (2-tailed).
}

* Significant at the 0.05 level (2-tailed). 
Table 5. - Estimates of genetic parameters of various studied traits.

\begin{tabular}{|l|c|c|c|c|c|}
\hline Parameters & Height & Bole length & $\begin{array}{c}\text { Collar } \\
\text { diameter }\end{array}$ & $\begin{array}{c}\text { Branch } \\
\text { Number }\end{array}$ & Survival \\
\hline General mean & 6.38 & 1.57 & 6.75 & 22.92 & 74.99 \\
\hline Error variance & 0.38 & 0.11 & 0.53 & 13.22 & 120.38 \\
\hline $\begin{array}{l}\text { Genotypic variance } \\
\text { Phenotypic variance }\end{array}$ & 0.38 & 0.26 & 0.13 & 1.173 & 79.62 \\
\hline $\begin{array}{l}\text { Genotypic caefficient of } \\
\text { variance }\end{array}$ & 9.76 & 0.379 & 0.64 & 14.39 & 200.00 \\
\hline $\begin{array}{l}\text { Phenotypic coefficient } \\
\text { of variance }\end{array}$ & 13.70 & 39.21 & 11.88 & 16.55 & 18.85 \\
\hline \begin{tabular}{l} 
Heritability (\%) \\
\hline $\begin{array}{l}\text { Genetic gain (as \% of } \\
\text { mean) }\end{array}$
\end{tabular} & 50.30 & 69.70 & 17.97 & 8.15 & 39.81 \\
\hline
\end{tabular}

cant positive relationship with the collar diameter and branches at the same age, and with clear bole length at 24 months. Height at age 6 month also correlated with the heights of 12 and 24 months. Nursery growth traits did not indicate any significant relationship with the 24 months field growth.

Variance components and broad sense heritability for growth traits are given in Table 5. There were fair differences between the values of genotypic and phenotypic variance and genotypic and phenotypic co-efficient of variation for all the characters. Estimates of heritability (\%) of growth traits were moderate to high and ranged from 8.15 to $69.70 \%$. High heritability was obtained for clear bole length and tree height, however the values were low for collar diameter and number of branches.

\section{Discussion}

The results obtained from the trial indicate that genetic differences exist among the sources of $E$. camaldulensis. Seed sources depicted a similar pattern in their performance with regard to height, collar diameter and number of branches and also varied significantly $(\mathrm{P}<0.001)$, except field survival. The two sources ranked high in survival and growth viz. Laura river, QLD and Emu Creek Petford, QLD and are recommended for large scale planting at Seothi and nearby sites under semi-arid conditions. The results have shown a distinct pattern of superiority of these two seed sources than the rest. Results obtained at age $8-10$ years are in confirmation with the findings of LACAZE $(1970,1978)$ through his 24 well designed field trials in 14 Mediterranean and tropical countries. Present findings at the age of two years of two sources and a similar confirmatory pattern of growth rate in different corners of the world could lead us to use Laura River and Petford, Queensland provenances for large scale planting programmes, instead of waiting for few more years to confirm the results. It is worthwhile to mention here that $E$. camaldulensis shows a strong juvenile and mature correlation, as has been confirmed by LACAZE (1970, 1978) and BARRETT and CARTER (1970). Hence the performance of these two sources at age two is expected to remain consistent throughout their age.

It is interesting to note that of the two promising sources as emerged from the present investigation, i.e. Petford, Queensland, is also known to show a stable performance when was grown in India (RAO, 1984), Bangladesh (DAVIDSON and DAS, 1985) and Brazil (MourA, 1986). It indicates that, this source possesses an inherent capacity for fast growth and is stable over changing environmental conditions.

The inter relationship between height and collar diameter, height and field survival (12 month age) suggests that such characters can be used to the advantage of the breeder and simultaneous improvement of the character can be brought about easily. Also the relationships between the same traits of different age groups are quite significant (except for the nursery stage), which indicates the consistent pattern of performance of the sources with the age. Nursery growth traits did not reveal any significant correlation with the field growth, which confirm that the predictions based on the nursery stage performance alone may not be reliable. The seedlings should face the actual field conditions before their genetic potential is judged. The early field growth performance (6 months) has been consistence throughout the age ( 24 months).

The success or failure of tree breeding depends largely on the extent of variability in the base population, which is measured by different population parameters including genotypic and phenotypic variations and genotypic and phenotypic coefficient of variation (SUBRAMANIAN et al., 1995). In the present study, there were considerable differences between the genotypic and phenotypic coefficients of variation for all the characters, which indicates that these characters are sensitive to environmental changes (SUBRAMANIAN et al., 1995). The genotypic coefficient of variations are comparatively lower than phenotypic coefficient of variation for all the traits. This has also been reported by RATHINAM et al. (1982) for height and girth, and SUBRAMANIAN et al. (1995) for height, girth and clear bole length.

Heritability estimates indicate the relative value of selection of the material in hand. The broad sense heritability, for height and clear bole length were fairly high. These traits are, probably under the influence of additive gene effect. This also suggests that the gains from the selection will be high in the base population. To arrive at a more reliable estimate, heritability and genetic advance values are considered jointly (SuBRAMANIAN et al., 1995). The genetic gain at the age of 24 months indicate that there was a fair relationship between phenotype and genotype and existence of considerable variability for the traits studied.

Variation in Eucalyptus camaldulensis sources with respect to growth performance could be due to the fact that this species grows over a wide range of rainfall, temperature and soil types in Australia. Populations must have experienced marked differences in selective pressure. From the present and previous investigations it is quite clear that Laura river, QLD and Emu Creek Petford, QLD sources are quite good in their performance in different environmental conditions. This gives us a direction and opportunities to effect genetic improvement in the species.

\section{Acknowledgement}

The authors are grateful to Dr. ChRIS HARwOOD, CSIRO, Canberra, Australia for providing seed lots of Eucalyptus camaldulensis for conducting the experiment.

\section{References}

BARRETt, R. L. and CARTER, D. T. (1970): Eucalyptus camaldulensis provenances trials in Rhodesia (part 1, early results). Research Bulletin 2 (Part 1). Rhodesia Forestry Commission, Salisbury.

DAVIDSON, J. and DAS, S. (eds.). (1985): Eucalyptus in Bangladesh. Silviculture Division Bulletin No. 6. Bangladesh Forest Research Institute, Chittagong.

Destremau, D. X., Jolly, H., and Korba, M. (1973): Les enseignements de 1' essai comparative de provenances d' Eucalyptus camaldulensis de Sidi Slimane. Annales de la Recherche Forestiere au Maroc 13: 121-154.

Eldridge, K., Davidson, J., HaRwood, C. and WyK, G. (1994): Eucalypts Domestication and Breeding. Clarendon press. Oxford. Pp. 228-229.

Emery, B. M. and Ledig, F. T. (1987): Provenance variation in Eucalyptus camaldulensis Dehnh. in California. Silvae Genetica 36: 172-180.

KARSCHON, R. (1974): The relation of seed origin to growth of Eucalyptus camaldulensis Dehn. in Israel. Israel Journal of Agricultural Research 23 (3-4): 159-173. 
KempthoRNe, O. (1957): An Introduction to Genetic Statistics. John Willey and Sons Lt., New York: 101-146.

Kumarvelu, G., Stanley, J., Rai, V. and Sampson, B. (1995): Provenances of Eucalyptus camaldulensis Dehnh and E. tereticornis $\mathrm{Sm}$ suitable to south Indian conditions - results of an IUFRO trial. Annals of Forestry 3(2): 129-133.

LACAZE, J. F. (1970): Studies on the ecological adaptation of Eucalyptus. Operational report for 1970 on project No. 6 . Document, $4^{\text {th }}$ Session Committee on the Coordination of Mediterranean Forestry Problems, Ankara, No. FO: SCM/FR 70/2/10. FAO, Rome.

LACAZE, J. F. (1978): Eucalyptus camaldulensis, Project FAO no. 6. In: Documents FAO third world consultation on forest tree breeding Vol. 1: 393-409. CSIRO, Canberra.

MoReshet, S. (1981): Physiological activity, in a semi arid environment, of Eucalyptus camaldulensis Dehn. from two provenances. Australian Journal of Botany 29: 97-110.
MourA, V. P. G. (1986): Provenance variation of Eucalyptus camaldulensis Dehnh. in Brazil. Unpublished D. Phil. thesis, University of Oxford.

RAO, D.V. (1984): Provenance trial of Eucalyptus. Indian Forester 110: 28-34.

RATHINAM, M., Suerndran, C. and KondAS, S. (1982): Interrelationship of wood yield component in Eucalyptus tereticornis Sm. Indian Forester 108: 460-470.

SidDiqUi, K. M., KJAN, M., and AKHTAR, S. (1979): Results of 10 year old Eucalyptus camaldulensis Dehn. provenance study at Peshwar. Silvae Genetica 28: 24-26.

SNEDECOR, G. W. and Cochran, W. G. (1967): Statistical Methods. Oxford and IBH, New Delhi. 593 pp.

Subramanian, K. N., Mandal, A. K. and Nicodemus, A. (1995): Genetic variability and character association in Eucalyptus grandis. Annals of Forestry 3 (2): 134-137.

\title{
Seed Source Variation in Growth Performance and Oil Yield of Jatropha curcas Linn. in Central India
}

\author{
By H. S. GinWAL", P. S. Rawat ${ }^{1}$ and R. L. SRIVASTAVA ${ }^{2}$ \\ Division of Genetics and Tree Propagation, Forest Research Institute, P.O. I.P.E. Kaulagarh Road, \\ Dehradun 248195 (Uttaranchal) India \\ (Received 27 $7^{\text {th }}$ October 2004)
}

\begin{abstract}
Results of a seed source evaluation trial of Jatropha curcas Linn. laid out in 1996 at Jabalpur (M.P), a semi arid region of India are reported and discussed. Seeds collected from ten sources from central India representing the states Madhya Pradesh and Maharashtra viz. Gondia, Bichia, Balaghat, Niwas, Khandwa, Burhanpur, Nasik, Chindwara, Kundam and Jabalpur were evaluated for their growth performance from nursery stage ( 3 months) to field (two years). Variation in seed oil content of different sources were also studied and reported. Significant differences between the seed sources at age 27 months were observed for height, collar diameter, number of branches leaf area and field survival. Seeds collected from different sources also varied significantly in respect of seed and kernel weight and oil content in seed/kernel. The Chhindwara (M.P.) source performed the best and yielded a maximum oil of $39.12 \%$ from whole seed and $58.12 \%$ from kernel. The oil content ranged from 33.02 to $39.12 \%$ in whole seeds and 47.08 to $58.12 \%$ in kernel, across the seed sources. The performance of Kundam (M.P.), Jabalpur (M.P.), Bichia (M.P.), Niwas (M.P.) and Nasik (Maharashtra) sources were also found satisfactory for oil yield. Results indicate that genetic differences exist between the seed sources of J. curcas. The growth traits showed significant positive correlation with each other. Fair differences between phenotypic and genotypic coefficient of variability were observed. Heritability (broad sense) values

\footnotetext{
* Author for correspondence: (e-mail: ginwalhs@icfre.org; ginwalhs@rediffmail.com)

${ }^{1}$ Division of Forest Pathology, Forest Research Institute, P.O. New Forest, Dehradun 248006 (Uttaranchal) India

${ }^{2}$ Arid Forest Research Institute, Jodhpur (Rajasthan), India.
}

were fairly good with regard to leaf area, height and collar diameter in comparison to survival percent. The relative performance of these sources was fairly consistent throughout the observation period.

Key words: Jatropha curcas, variation, provenance, genetic improvement, productivity, heritability, oil, diesel.

\section{Introduction}

Jatropha cuurcas Linn. (tropical physic nut) belonging to family Euphorbiaceae is a native species of tropical America, cultivated throughout the tropics and is sub-spontaneous in Mauritius and Seychelles (BAKER, 1877). It is a very prominent and widely acclaimed species with vide variety of uses. It is a small tree or large shrub, which can reach height of up to $5 \mathrm{~m}$ and has high potential for greening and eco-rehabilitation of wastelands as well as for bio-aesthetic reasons (HELLER, 1996). In India, it is found in semi-wild conditions in the vicinity of villages and is one of the most promising drought tolerant perennial plant adapted to various kinds of soil conditions (SRIVASTAVA, 1999). The plant is widely distributed and fits easily into agricultural systems in the form of hedges, windbreak, anti erosion barrier or source of firewood (SRIVASTAVA, 1999).

In the recent years energy conservation and its production has acquired significant importance in the wake of the world energy crisis. A number of options for production of liquid fuel as an alternative source have been considered in many countries. Oil seed crops are potential renewable sources of fuels and in this category $J$. curcas has won over the interest of various developmental agencies. The J. curcas oil has been identified as an efficient substitute to be used as fuel for diesel 